\title{
Purification of carp growth hormone and cloning of the complementary DNA
}

\author{
Shiow-Chyi Chao, Fu-Ming Pan and Wen-Chang Chang \\ Institute of Biochemical Sciences, National Tuiwan University and Institute of Biological Chemistry, Academia Sinica, Taipei, \\ (Taiwan, China)
}

(Received 23 August 1988)

(Revised manuscript received 11 November 1988)

Key words: Growth hormone; cDNA sequence; Amino acid sequence; Sequence homology; (Carp, C. carpico)

The growth hormone (GH) was isolated and purified from common carp (Cyprimess carpio) pituitary glands by salt precipitativat dad HPLC on reverse-phase C18 columns. The carp GH CDNA was synthesized and cloned in Escherichica coli using Eco RII linkers and pBR322 as vector. The positive clones weve selected and sequenced. The full-length carp GH CDNA contains 1187 nucleotide basepairs with an open reading frame coding for the precursor form carp GH of 210 amino-acid residues. The partial amimowncid sequence from the protein completely agrees with that derived from the CDNA, with serine as the first residue in mature carp GH preceded by 22-residue hydrophobic signal peptide. Comparison of the amino-acid sequence of carp GH with those of various species reveals positional identity at $32.4 \%$, $38.8 \%, 42.0 \%, 37.2 \%, 66 \%, 55 \%$ and $49 \%$ with GHs of man, rat, duck, bullfrog, salmon, tuna and yellow tail, respectively.

Growth hormones, which are secreted from pituitary glands, are required for normal growth and development pre-adult. Recently, the primary structure of the GH of the chum salmon has been determined $[1,2]$ and the cDNA for the GHs of chum salmon [3], rainbow trout [4], tuna [5], coho salmon [6,7], red sea bream [8] and yellow tail [9] have been cloned. We have purified carp GH from pituitary glands and have determined the $\mathrm{N}$-terminal amino-acid sequence. The cDNA has been cloned and sequenced. The results are described in this report.

The carp $\mathrm{GH}$ has been purified according to previous procedures [10]. It was identified by the precipitin reaction with antiserum against tilapia $\mathrm{GH}$. The amino-acid sequence was determined in a pulse-liquid phase protein sequencer (Applied Biosystems Inc. 477A). The mRNA was prepared by the guanidinium/cesium chloride method [11] followed by two-cycle chromatography on oligo(dT)-cellulose column [12]. Double-stranded cDNA

The sequence data in this paper have been submitted to the EMBL/Genbank Date Libraries under the accession number $\times 13670$.

Abbreviation: GH, growth hormone.

Correspondence: W.C. Chang, Institute of Biological Chemistry, Academia Sinica, P.O. Box 23-106, Taipei, Taiwan, Republic of China. was prepared by the method of Gubler and Hoffman [13], methylated with EcoRI methylase, ligated with EcoRI linkers, cut with EcoRI and then sizefractionated by electrophoresis on $1.0 \%$ agarose gel. The cDNA with size of 0.8-1.2 kilobasepairs was recovered from the gel and ligated with EcoRI-cleaved pBR322. The resulting plasmids were introduced into $E$. coli HB101 cells.

The cDNA library was screened by Southern blot hybridization with nick-translated salmon GH cDNA. One of the positive clones was sequenced by the method of Maxam and Gilbert [14] and the chain-termination method of Sanger [15] as shown in Fig. 1. The carp GH cDNA contains 1187 nucleotide base pairs with an open reading frame coding for 210 amino-acid residues (Fig. 2). The N-terminal amino-acid sequence was de-

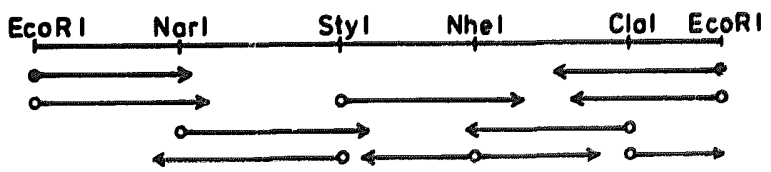

$100 \mathrm{bp}$

Fig. 1. Restriction map and sequencing strategy of the carp GH cDNA. The solid circles indicate the starting point of dideoxy quencing, whereas the open ones are the end-labelling sites for chem. ical sequencing. 


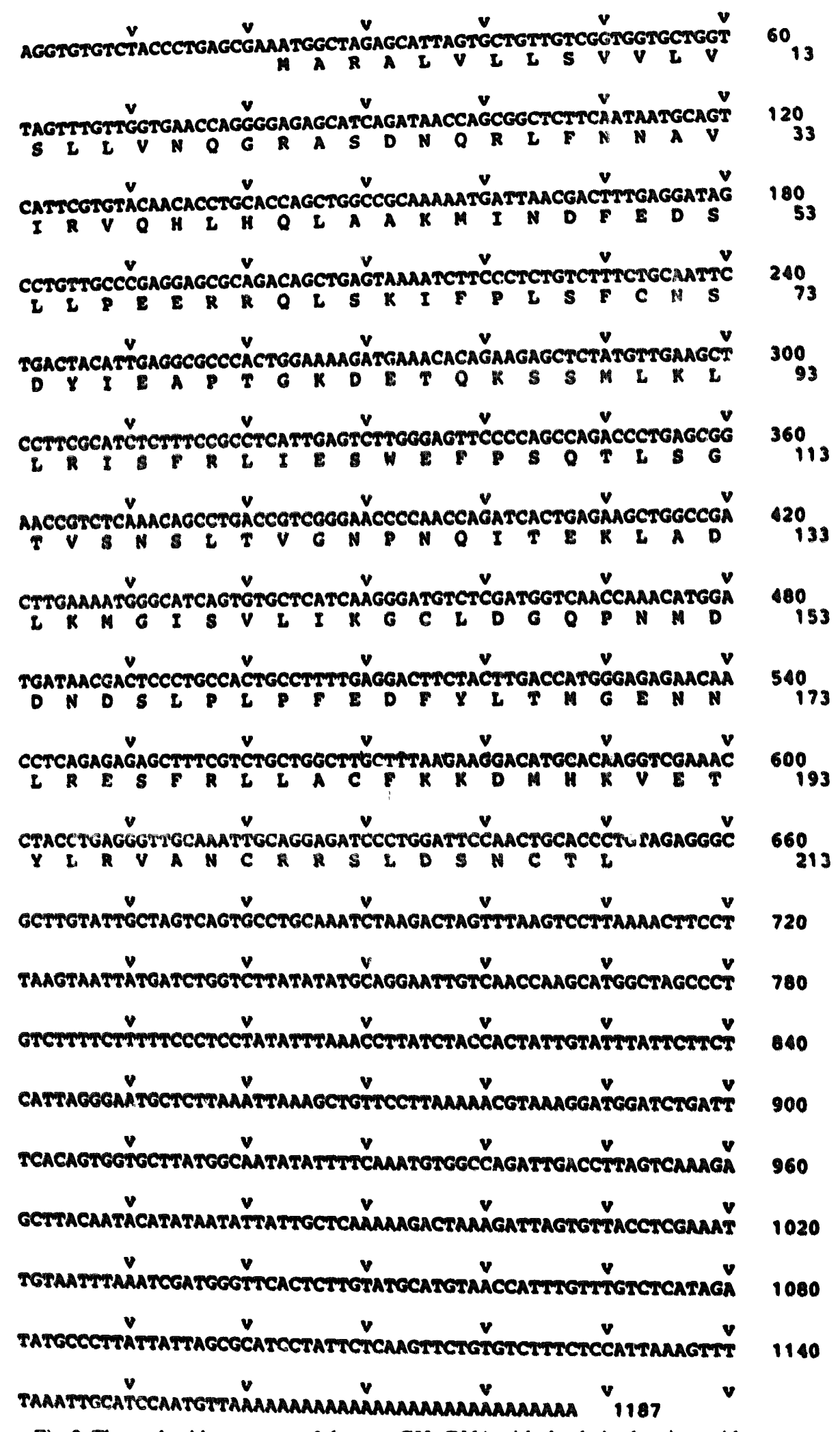

Fig. 2. The nucleotide sequence of the carp GH cDNA with the derived amino-acid sequence.

termined with an automatic protein sequencer as shown below:

H,N-SDNORLFNNAVIRVOHLHOLAKMINDFE
The sequence completely agrees with the amino-acid sequence derived from the nucleotide sequence, with serine as the first residue in mature carp GH.

Comparison of amino-acid sequence between carp GH and other GHs (Fig. 3) reveals that carp GH shares 


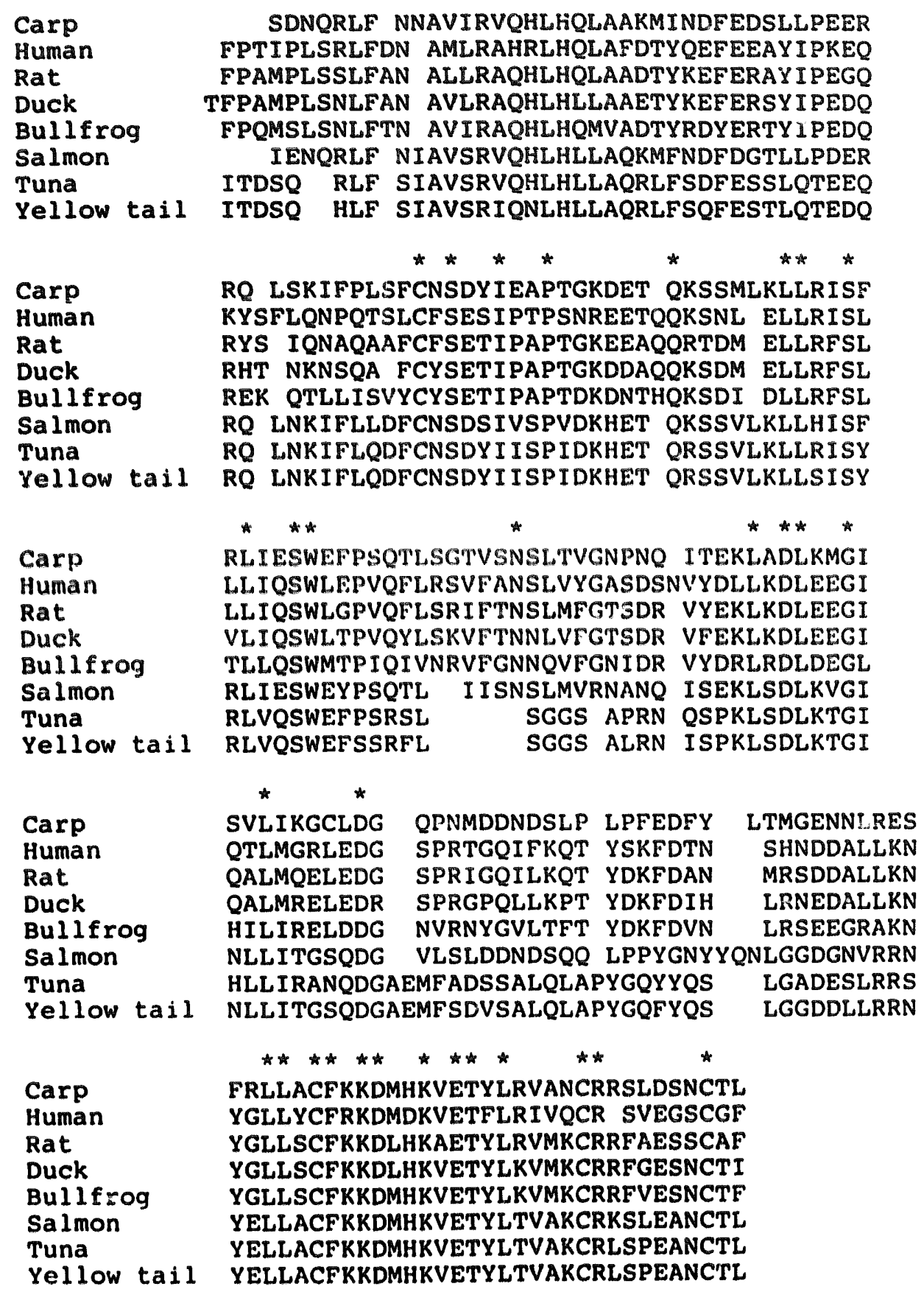

Fig. 3. Comparison of amino-acid sequences of GHs of carp (the present study), human [16], rat [17], duck [10], bullfrog [18], salmon [3], tuna [5] and yellow tail [9]. The salmon sequence is identical to that of GH of rainbow trout [4]. Gaps are introduced to maximize similarity. Asterisks indicate the invariant residues for all sequences.

$32.4 \%, 38.8 \%, 42.0 \%, 37.2 \%, 66.0 \%, 55 \%$ and $49 \%$ sequence similarity with the GHs of human [16], rat [17], duck [10], bullfrog [18], salmon [3], tuna [5] and yellow tail [9], respectively. The invariant residues are predominantly located within the $a$-helices which are necessary to maintain the structural integrity of these proteins and are not required for species specificity [19]. It is interesting that the $3^{\prime}$-untranslated region of carp GH mRNA as well as salmon GH mRNA is longer than those of mammalian GHs. In another respect, $G$ and $C$ are highly favored in the third position of the codons for rat
[17] and human [16] growth hormones, but are less favored in carp $\mathrm{GH}$.

We thank Dr. C.L. Hew, Department of Clinical Biochemistry, University of Toronto, for the salmon GH cDNA. This work was financially supported by the National Science Council of Republic of China.

\section{References}

1 Yasuda, A., Hiromichi, 1. and Kawauchi, H. (1986) Arch. Biochem. Biophys. 244, 528-541. 
2 Kawauchi, H., Maruyama, S., Yasuda, A., Yamaguchi, K., Shirabata, K., Kubota, J. and Hirano, T. (1986) Arch. Biochem. Biophys. 244, 542-552.

3 Sekine, S., Mizukami, T., Nishi, T., Kuwana, Y., Saito, A., Sato, M., Itoh, S. and Kawauchi, H. (1985) Proc. Natl. Acad. Sci. USA 82, 4306-4310.

4 Agellon, L.B. and Chen, T.T. (1986) DNA 5, 463-471.

5 Sato, N., Watanabe, K., Murata, K., Sakaguchi, M., Kariya, Y., Kimura, S., Nonaka, M. and Kimura, A. (1988) Biochim. Biophys. Acta 949, 35-42.

6 Gonzalez-Villaseñor, L.I., Zhang, P., Chen, T.T. and Powers, D.A. (1988) Gene 65, 239-246.

7 Nicoll, C.S., Steiny, S.S., King, D.S., Nishioka, R.S., Mayer, G.L., Eberhardt, N.L., Baxter, J.D., Yamanaka, M.K., Miller, J.A., Seilhamer, J.J., Schilling, J.W. and Johnson, L.K. (1987) Gen. Comp. Endocrinol, 68, 387-399.

8 Momota, H, Kosugi, R. Hiramatsu, H., Ohgai, H., Hara, A. and I Shioka, H, (1988) Nucleic Acids Res. 16, 3107.

9 Watahiki, M., Tanaka, M., Masuda, N., Yamakawa, M. Yoneda, $Y$, and Nakashima, K. (1988) Gen. Comp. Endocrinol. 70, $401=406$.

10 Chen, H.T., Pan, F.M. and Chang, W.C. (1988) Biochim. Biophys. Acta $949.247=251$.
11 Maniatis, T., Fritsch, E.F. and Sambrook, J. (1982) Molecular Cloning: A Laboratory Manual, p. 196, Cold Spring Harbor Laboratory, Cold Spring Harbor, NY.

12 Aviv, H. and Leder, P. (1972) Proc. Natl. Acad. Sci. USA 69, 1408-1412.

13 Gubler, U. and Hoffman, B.J. (1983) Gene 25, 263-269.

14 Maxam, A.M. and Gilbert, W. (1980) Methods Enzymol. 65, 499-560.

15 Sanger, F., Nicklen, S. and Coulson, A.R. (1977) Proc. Natl. Acad. Sci. USA 74, 5463-5467.

16 Martial, J.A., Hallewell, R.A., Baxter, J.D. and Goodman, H.M. (1979) Science 205, 602-607.

17 Seeburg, P.H., Shine, J., Martial, J.A., Baxter, J.D. and Goodman, H.M. (1977) Nature (London) 270, 486-494.

18 Pan, F.M. and Chang, W.C. (1988) Biochim. Biophys. Acta 950, $238=242$.

19 Abdel-Meguid, S.S., Shieh, H.S., Smith, W.W., Dayringer, H.E., Violand, B.N. and Bentle, L.A. (1987) Proc. Natl. Acad. Sci. USA $84,6434=6437$. 